\title{
Penerapan model pembelajaran Creative Problem Solving (CPS) untuk meningkatkan hasil belajar siswa kelas VI SDN 02 Talun Kabupaten Pekalongan
}

\author{
Asep Tri Prasetiyo \\ SDN 02 Talun, Kabupaten Pekalongan
}

\begin{tabular}{|c|c|}
\hline Article Info & ABSTRACT \\
\hline $\begin{array}{l}\text { Article history: } \\
\text { Received : } 20 \text { Juli } 2021 \\
\text { Revised : } 6 \text { September } 2021 \\
\text { Accepted : } 20 \text { September } 2021\end{array}$ & $\begin{array}{l}\text { The problem in this classroom action research is whether the learning } \\
\text { outcomes of class VI students at SDN } 02 \text { Talun, Pekalongan Regency can be } \\
\text { improved through the implementation of creative problem solving (CPS) } \\
\text { models? The purpose of this classroom action research is to find out whether } \\
\text { the application of the CPS learning model can improve student learning }\end{array}$ \\
\hline $\begin{array}{l}\text { Keywords: } \\
\text { cps; learning model; learning } \\
\text { outcomes }\end{array}$ & $\begin{array}{l}\text { with the applied creative problem solving learning model. The subjects in } \\
\text { this classroom action research were } 28 \text { students of class VI. This classroom } \\
\text { action research was conducted in } 2 \text { cycles where each cycle consisted of } 2 \\
\text { learning meetings. The indicator of the success of this research is that student } \\
\text { learning outcomes increase if the average student learning outcomes reach an } \\
\text { average value of } 70 \text { and the number of students who complete learning is } \\
85 \% \text {. The results of this classroom action research indicate an increase in } \\
\text { student learning outcomes in the evaluation of cycles I and II, namely an } \\
\text { increase in the class average value from } 71.75 \text { to } 76.63 \text { with the percentage } \\
\text { of classical completeness in cycle I reaching } 75 \% \text { and cycle II reaching } \\
89.28 \text {. } \% \text {. The increase in student learning outcomes was followed by } \\
\text { changes in the level of student activity during learning, namely the first cycle } \\
\text { from } 67.5 \% \text { to } 85 \% \text { in the second cycle. Observation of teacher activities has } \\
\text { increased from } 75 \% \text { in the first cycle to } 90 \% \text { in the second cycle. Based on } \\
\text { the results of these studies, suggestions that can be given are the need to } \\
\text { apply the CPS learning model to improve learning outcomes and student } \\
\text { activity. }\end{array}$ \\
\hline
\end{tabular}

(*) Corresponding Author:

tiogupa@gmail.com

How to Cite: Prasetiyo, A. T (2021). Penerapan Model Pembelajaran Creative Problem Solving (CPS) untuk meningkatkan hasil belajar siswa kelas VI SDN 02 Talun Kabupaten Pekalongan. Action Research Journal, 1(1): $19-24$.

\section{PENDAHULUAN}

Berhasil tidaknya tujuan pengajaran banyak tergantung pada proses kegiatan belajar mengajar yang dilakukan oleh guru dikelas tanpa mengesampingkan faktor-faktor pendidikan yang lain seperti kurikulum, sarana dan prasarana pendidikan. Guru sebagai fasilitator belajar siswa harus bisa memahami kesukaran yang dialami oleh siswa (Udayani \& Agustika, 2018; Sari \& Noer, 2017). Guru harus mampu memilih model pembelajaran sesuai dengan materi pelajaran sehingga dapat mempermudah siswa mencerna pelajaran yang disampaikan oleh guru karena penyajian guru yang menarik.

Berdasarkan hasil pengamatan peneliti sebagai guru kelas VI SDN 02 Talun Kabupaten Pekalongan diperoleh informasi bahwa keaktifan dan hasil belajar siswa rendah. Ini dapat dilihat dari hasil nilai rata-rata kelas yang masih rendah yaitu kurang dari 70. Minat siswa dalam belajar matematika masih rendah, kreativitas dan keterlibatan siswa dalam aktivitas belajar juga masih rendah, akibatnya siswa saat menemui permasalahan matematika menjadi bingung dan kesulitan untuk memecahkan permasalahan yang telah ditemuinya. 
Untuk mengatasi permasalahan tersebut, akan diterapkan pembelajaran creative problem solving. Ide utama dari model creative problem solving ini adalah merangsang peserta didik untuk dapat berperan secara aktif, dan lebih terampil dalam menganalisis suatu masalah serta mampu mengurangi rasa kejenuhan siswa pada proses belajar mengajar (Yuliati \& Lestari, 2019; Partayasa, Suharta, \& Suparta, 2020). Maka saat menemui permasalah matematika siswa tidak akan merasa kebingungan dan kesulitan lagi dalam memecahkan masalah yang ditemuinya. Sehingga hasil belajar siswa pun akan lebih optimal dan meningkat daripada sebelumnya. Model Pembelajaran creative problem solving merupakan model pembelajaran yang memusatkan pengajaran dan ketrampilan pemecahan masalah yang diikuti dengan penguatan ketrampilan (Harefa et al., 2020; Septian, Komala, \& Komara, 2019). Ketika dihadapkan pada suatu pertanyaan, siswa dapat melakukan keterampilan untuk memecahkan masalah, untuk memilih dan mengembangkan tanggapannya. Tidak hanya dengan cara menghafal tanpa dipikir, keterampilan memecahkan masalah memperluas proses berpikir (Muhammad, Septian, \& Sofa, 2018).

Implementasi dari model pembelajaran Creative Problem Solving, terdiri dari langkahlangkah sebagai berikut: 1) Guru menanyakan kesiapan siswa selama pelajaran matematika berlangsung, mengulas kembali materi sebelumnya mengenai materi yang dijadikan sebagai prasyarat pada materi saat ini kemudian guru menjelaskan aturan main ketika model pembelajaran creative problem solving serta guru memberi motivasi kepada siswa. 2) Siswa membentuk kelompok kecil untuk melakukan small discussion. Siswa memecahkan permasalahan yang terdapat dalam bahan ajar siswa sesuai petunjuk yang terdapat di dalamnya. Peranan guru menciptakan situasi yang dapat memudahkan munculnya pertanyaan dan mengarahkan kegiatan brainstrorming serta menumbuhkan situasi yang mendukung. 3) Sebagai pemantapan materi, secara individu siswa mengerjakan soal dan memberikan motivasi siswa mengerjakan soal matematika (Abduloh, Karomah, \& Hidayati, 2018; Malisa, Bakti, \& Iriani, 2018; Pramestika, Suwignyo, \& Utaya, 2020).

\section{METODE}

Penelitian dengan pembelajaran Creative Problem Solving dilakukan untuk meningkatkan hasil belajar siswa, meningkatkan keaktifan siswa dalam pembelajaran. Penelitian tindakan kelas ini direncanakan akan dilakukan dalam dua siklus. Setiap siklus meliputi tahapan perencanaan, tindakan, observasi dan refleksi. Gambar 1 menunjukkan tahapan dari pelaksanaan penelitian tindakan ini. Subjek penelitian ini adalah siswa kelas V SDN 02 Talun Kabupaten Pekalongan sejumlah 28 siswa. Adapun yang menjadi objek dalam penelitian ini adalah peningkatan hasil belajar siswa kelas. Faktor yang hendak diteliti dalam penelitian in adalah: hasil belajar siswa berupa kemampuan kognitif dalam memecahkan masalah setelah diterapkan pembelajharan dengan model pembelajaran creative problem solving, keaktifan siswa selama kegiatan belajar mengajar berlangsung, dan cara guru merencanakan serta melaksanakan pembelajaran dengan model pembelajaran creative problem solving (Abduloh, Karomah, \& Hidayati, 2018; Malisa, Bakti, \& Iriani, 2018; Pramestika, Suwignyo, \& Utaya, 2020).

Teknik tes digunakan untuk memperoleh data hasil belajar siswa sesudah diadakan pembelajaran dengan model pembelajaran Creative Problem Solving dan untuk menjawab permasalahan dalam penelitian. Tes dilakukan sebanyak dua kali yaitu pada akhir siklus I dan pada akhir siklus II. Sedangkan teknik non tes yang digunakan adalah observasi. Observasi digunakan untuk mengetahui sikap dan perilaku siswa terhadap pembelajaran matematika. Di samping itu juga observasi dilakukan terhadap peneliti untuk mengetahui sejauhmana peneliti telah melakukan hal-hal yang diharapkan selama proses pembelajaran berlangsung pada siklus I dan siklus II. 


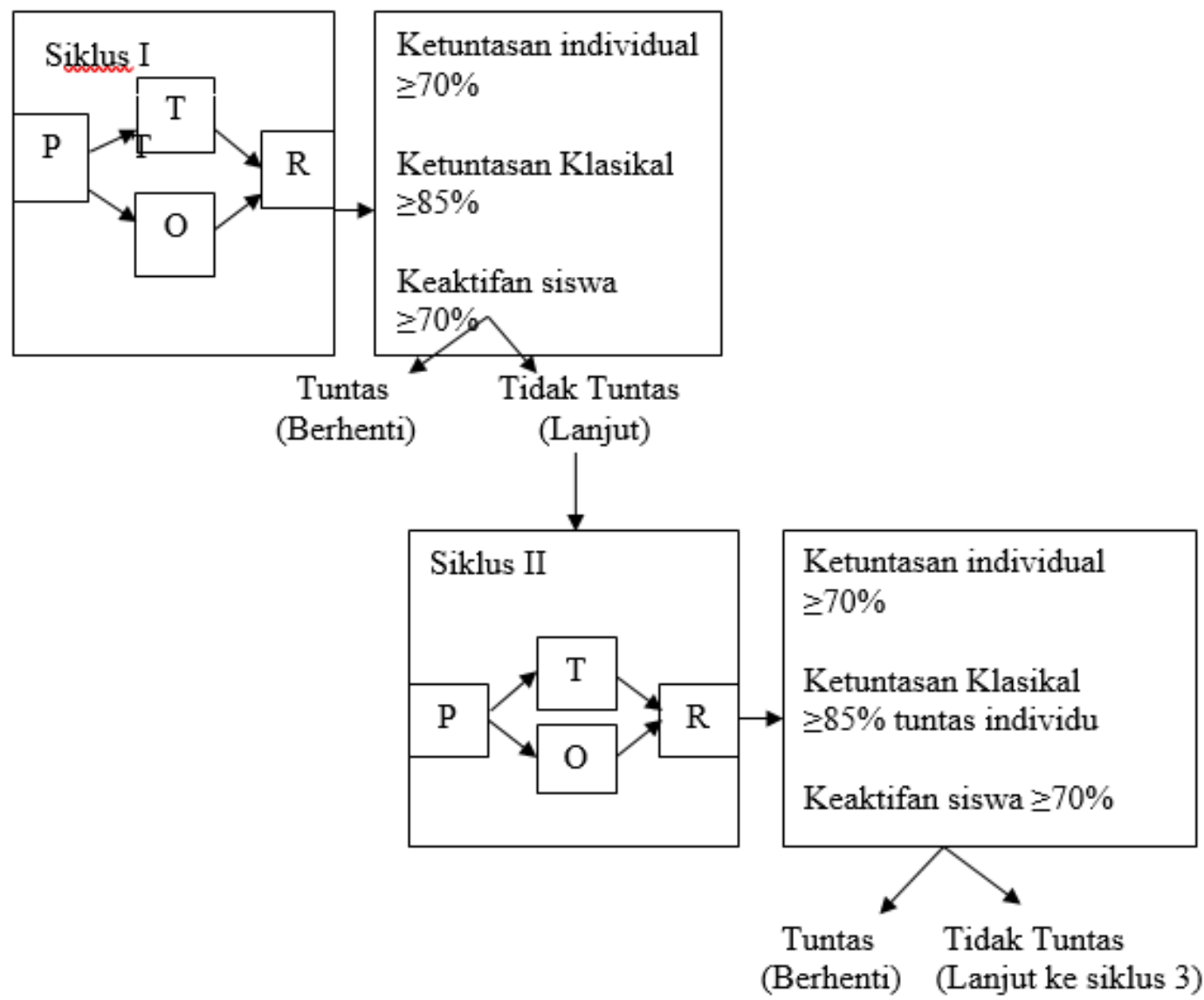

Gambar 1. Pelaksanaan Penelitian Tindakan Kelas

Data penelitian diolah secara deskriptif, dan silakukan refleksi setiap siklus untuk membuat simpulan dari kegiatan dan tindakan serta sikap siswa yang terjadi selama proses pembelajaran. Refleksi dilakukan untuk mengetahui peningkatkan hasil belajar matematika siswa dan perubahan tingkah laku siswa setelah dilakukan tindakan perbaikan dengan indikator keberhasilan yang digunakan yaitu niali minimal yang dicapai siswa adalah 70 dengan ketuntasan klasikal sekurang-kurangnya $85 \%$ dan keaktifan siswa selama proses pembelajaran $\geq 70 \%$. Dengan refleksi ini juga digunakan untuk mengetahui bahwa dengan penerapan model pembelajaran Creative Problem Solving dapat meningkatkan hasil belajar siswa.

\section{HASIL DAN PEMBAHASAN}

\section{Hasil}

Setelah persiapan dilakukan maka langkah selanjutnya adalah pelaksanaan penelitian. Penelitian ini dirancang dalam dua siklus dan tiap siklus terdiri dari empat tahapan, yaitu tahap perencanaan, tindakan, pengamatan, dan refleksi. Adapun tahapan tiap siklus dapat diuraikan sebagai berikut :

Siklus I

Kegiatan siklus I menggunakan rencana pembelajaran, lembar kerja siswa, uji kompetensi/evaluasi. Adapun uraian kegiatan siklus I dijelaskan sebagai berikut:

Perencanaan

1. Guru dan observer menyiapkan batasan materi ajar

2. Menyusun rencana pembelajaran dan perangkat pembelajaran

3. Menyiapkan lembar observasi tentang keaktifan siswa, lembar observasi keaktifan guru, dan lembar observasi kerjasama

4. Membuat soal tes siklus I 


\section{Pelaksanaan Tindakan}

Tindakan siklus I pada penelitian ini dilaksanakan terdiri dari 2 kali pertemuan. Pertemuan pertama dengan kegiatan pembelajaran di kelas dan menyelesaikan soal latihan pada lembar kerja yang sudah disediakan sesuai dengan kelompoknya masing-masing. Pertemuan kedua adalah pelaksanaan evaluasi. Adapun tindakan yang dilakukan adalah sebagai berikut:

1. Guru menjelaskan tentang tujuan pembelajaran.

2. Guru mengelompokkan siswa menjadi beberapa kelompok

3. Guru membagikan LKS pada masing-masing kelompok untuk dibahas

4. Guru membantu siswa yang mengalami kesulitan dalam menentukan cara pemecahan masalah yang dihadapi.

5. Guru membantu dan memberi motivasi siswa untuk merumuskan alternatif strategi penyelesaian masalah yang sesuai.

6. Guru meminta satu atau dua orang siswa untuk mendemonstrasikan hasil kerja kelompoknya dan meminta kelompok lain untuk menyangga atau bertanya jika ada yang belum jelas.

7. Guru bersama-sama dengan siswa menyimpulkan materi yang telah dipelajari.

Pengamatan

1. Hasil observasi terhadap guru pada saat proses pembelajaran siklus I diperoleh aktifitas guru mencapai $75 \%$ dengan kategori baik.

2. Hasil observasi keaktifan siswa pada saat pembelajaran siklus I adalah $68 \%$, dengan kategori cukup baik

3. Observasi hasil evaluasi atau hasil belajar siklus I diperoleh 21 siswa yang tuntas dan 7 siswa belum tuntas, dengan nilai rata-rata kelas dari 71,75.

\section{Refleksi}

Setelah mengadakan pengamatan pada proses pembelajaran, selanjutnya diadakan refleksi terhadap segala tindakan yang telah dilakukan. Dari pelaksanaan siklus I didapat hasil refleki sebagai berikut:

1. Agar tercipta pembelajaran yang aktif, maka guru harus melibatkan siswa.

2. Guru hendaknya memberikan perhatian dan memberikan pengertian agar siswa dapat bekerjasama dan membagi kemampuan yang dimiliki kepada temannya yang belum dapat memecahkan permasalahannya.

3. Guru harus mampu menumbuhkan minat siswa untuk bertanya.

Dari siklus I diperoleh bahwa keaktifan siswa memperoleh persentase $67,5 \%$ yang dikategorikan cukup baik. Namun terdapat beberapa catatan dari peneliti bahwa guru kurang memberikan motivasi siswa untuk bertanya, dan mengemukakan pendapatnya. Analisis hasil belajar siswa pada siklus I dalam proses pembelajaran dengan menggunakan model creative problem solving diperoleh siswa belum tuntas belajar berjumlah 7 siswa dengan persentase $25 \%$ sedangkan siswa yang mencapai tuntas belajar berjumlah 21 siswa dengan persentase $75 \%$, dan nilai rata-rata kelas yang dicapai adalah 71,75 . Dengan demikian perlu dilakukan perbaikan tindakan pada pelaksanaan siklus II.

Siklus II

\section{Perencanaan}

1. Guru dan observer menyiapkan batasan materi ajar

2. Menyusun rencana pembelajaran dan perangkat pembelajaran

3. Menyiapkan lembar observasi tentang keaktifan siswa, lembar observasi keaktifan guru, dan lembar observasi kerjasama

4. Membuat soal tes siklus II

Pelaksanan Tindakan

Tindakan siklus II pada penelitian ini dilaksanakan terdiri dari 2 kali pertemuan. Pertemuan pertama dengan kegiatan pembelajaran di kelas dan menyelesaikan soal latihan pada lembar kerja yang sudah disediakan sesuai dengan kelompoknya masing-masing. Pertemuan kedua adalah pelaksanaan evaluasi. Adapun tindakan yang dilakukan adalah sebagai berikut:

1. Guru menjelaskan tentang tujuan pembelajaran. 
2. Guru mengelompokkan siswa menjadi beberapa kelompok

3. Guru membagikan LKS pada masing-masing kelompok untuk dibahas

4. Guru membantu siswa yang mengalami kesulitan dalam menentukan cara pemecahan masalah yang dihadapi.

5. Guru membantu dan memberi motivasi siswa untuk merumuskan alternatif strategi penyelesaian masalah yang sesuai.

6. Guru meminta satu atau dua orang siswa untuk mendemonstrasikan hasil kerja kelompoknya dan meminta kelompok lain untuk menyangga atau bertanya jika ada yang belum jelas.

7. Guru bersama-sama dengan siswa menyimpulkan materi yang telah dipelajari.

Pengamatan

1. Hasil observasi terhadap guru pada saat proses pembelajaran siklus II diperoleh aktifitas guru mencapai $86,66 \%$ yang berarti sangat baik.

2. Hasil observasi keaktifan siswa pada saat pembelajaran siklus II mencapai $85 \%$ dengan kategori sangat baik

3. Hasil evaluasi belajar siklus II diperoleh $25(89,28 \%)$ siswa yang tuntas dan $3(10,72 \%)$ siswa yang belum tuntas.

Refleksi

Setelah mengadakan pengamatan pada proses pembelajaran, selanjutnya diadakan refleksi terhadap segala tindakan yang telah dilakukan. Dari pelaksanaan siklus II didapat hasil refleksi:

1. Pelaksanaan pembelajaran berjalan dengan baik, karena siswa memperhatikan penjelasan guru dan peran aktif bimbingan guru dalam pembelajaran sangat dirasakan siswa.

2. Penguasaan dengan model pembelajaran creative problem solving juga lebih baik.

3. Siswa lebih aktif bertanya dan mengemukakan pendapatnya.

Dari siklus II diperoleh bahwa keaktifan siswa memperoleh persentase $85 \%$ yang dikategorikan sangat tinggi dan telah memenuhi indikator keberhasilan yang telah ditetapkan. Peningkatan ini disebabkan karena kemampuan guru dalam memotivasi dan menumbuhkan keaktifan siswa lebih baik dari pada siklus I. Hasil analisis belajar pada siklus II diperoleh siswa yang tuntas belajar atau mendapatkan nilai $\geq 70$ telah mengalani peningkatan sebanyak 25 siswa dengan presentase $89,28 \%$ dan siswa yang tidak tuntas belajar atau mendapat nilai $<70$ sebanyak 3 siswa dengan presentase 10,72\% dengan nilai rata-rata 76,63. Dari hasil siklus II, ketuntasan ini telah memenuhi kriteria yang ditetapkan.

\section{Pembahasan}

Berdasarkan hasil penelitian dari siklus I dan II menujukan bahwa pembelajaran dengan model pembelajaran creative problem solving dapat meningkatkan hasil belajar siswa. Hal ini dapat ditunjukan dari hasil analisis evaluasi siklus I diketahui siswa yang tuntas belajar sebanyak 21 siswa dengan prosentase sebesar $75 \%$. Hal ini masih belum sesuai dengan indikator keberhasilan. Namun pada siklus II mengalami peningkatan, siswa yang tuntas belajar sebanyak 25 siswa dengan prosentase 89,28\%. Keaktifan siswa selama proses belajar mengajar mengalami peningkatan dari siklus I yang $67,5 \%$ menjadi $85 \%$ pada siklus II, walaupun masih ada sedikit siswa yang mengganggu siswa lain, tidak mendengarkan guru dan tidak mengerjakan tugas. Kegiatan siswa dalam mengikuti proses belajar mengajar pada siklus I dan siklus II sudah baik. Aktivitas guru pada siklus I sudah baik namun masih perlu ditingkatkan karena prosentase keaktifan guru hanya mencapai $75 \%$, sedangkan pada siklus II kemampuan guru dalam memotivasi dan membimbing siswa dalam pelaksanaan pembelajaran dengan model creative problem solving sudah sangat baik, hal ini dapat dilihat dari perolehan prosentase aktivitas guru yang meningkat sebesar $90 \%$.

Pada siklus II mengalami peningkatan dari siklus I, maka dapat dikatakan bahwa penelitian tindakan kelas ini sudah sesuai dengan indikator keberhasilan sehingga hipotesis tindakan dapat dicapai berdasarkan refleksi tes siklus I dan siklus II melalui penerapan model pembelajaran creative problem solving untuk meningkatkan hasil belajar siswa. Dengan demikian dapat dikatakan bahwa pembelajaran dengan menggunakan model pembelajaran creative problem solving dapat memotivasi dan meningkatkan keaktifan siswa pada saat proses 
belajar mengajar berlangsung (Harefa et al., 2020; Muhammad, Septian, \& Sofa, 2018). Sehingga model pembelajaran creative problem solving dapat menjadi solusi untuk meningkatkan hasil belajar siswa (Udayani \& Agustika, 2020; Yuliati \& Lestari, 2019).

\section{PENUTUP}

Berdasarkan hasil penelitian dan pembahasan, dapat disimpulkan bahwa pembelajaran dengan menggunakan model creative problem solving dapat meningkatkan prestasi belajar siswa. Hal ini ditunjukan dari hal-hal sebagai berikut :

1. Nilai rata-rata siklus I adalah 71,75 naik menjadi 76,63 pada sikus II. Hasil menunjukkan bahwa kemampuan siswa dalam menyelesaikan soal sesuai dengan indikator keberhasilan.

2. Untuk ketuntasan belajar, siklus I yang tuntas belajar $75 \%$ siswa dan pada siklus II yang tuntas belajar adalah $89,25 \%$ siswa. Hasil menunjukan tingkat penguasaan materi sudah sesuai dengan indikator keberhasilan.

3. Aktivitas siswa dalam pembelajaran siklus I adalah $67,5 \%$, sedangkan pada siklus II adalah $85 \%$. Hal ini menunjukan bahwa aktivitas siswa sudah sesuai dengan indikator keberhasilan.

4. Kinerja guru dalam pembelajaran siklus I adalah $75 \%$, sedangkan pada siklus II adalah $90 \%$. Hal ini menunjukan bahwa kinerja guru sudah sesuai dengan indikator keberhasilan.

\section{DAFTAR PUSTAKA}

Abduloh, U., Karomah, N., \& Hidayati, S. (2018). Peningkatan kemampuan pemecahan masalah matematika dalam soal literasi matematika melalui Model Creative Problem Solving Kelas VIII H SMPN 9 Semarang. In PRISMA, Prosiding Seminar Nasional Matematika (Vol. 1, pp. 774-780).

Harefa, D., Telaumbanua, T., Sarumaha, M., Ndururu, K., \& Ndururu, M. (2020). Peningkatan hasil belajar IPA pada model pembelajaran Creative Problem Solving (CPS). Musamus Journal of Primary Education, 1-18.

Malisa, S., Bakti, I., \& Iriani, R. (2018). Model Pembelajaran Creative Problem Solving (CPS) Untuk meningkatkan hasil belajar dan kemampuan berpikir kreatif siswa. Vidya Karya, 33(1), 1-20.

Muhammad, G. M., Septian, A., \& Sofa, M. I. (2018). Penggunaan model pembelajaran Creative Problem Solving untuk meningkatkan kemampuan pemecahan masalah matematis siswa. Mosharafa: Jurnal Pendidikan Matematika, 7(3), 315-326.

Partayasa, W., Suharta, I. G. P., \& Suparta, I. N. (2020). Pengaruh Model Creative Problem Solving (CPS) berbantuan video pembelajaran terhadap kemampuan pemecahan masalah ditinjau dari minat. JNPM (Jurnal Nasional Pendidikan Matematika), 4(1), 168-179.

Pramestika, R. A., Suwignyo, H., \& Utaya, S. (2020). Model Pembelajaran Creative Problem Solving pada kemampuan berpikir kreatif dan hasil belajar tematik siswa Sekolah Dasar. Jurnal Pendidikan: Teori, Penelitian, dan Pengembangan, 5(3), 361-366.

Sari, A. D., \& Noer, S. H. (2017). Kemampuan pemecahan masalah matematis dengan model Creative Problem Solving (CPS) dalam pembelajaran matematika. In Prosiding Seminar Nasional Matematika dan Pendidikan Matematika (Vol. 1, No. 1, pp. 245252).

Septian, A., Komala, E., \& Komara, K. A. (2019). Pembelajaran dengan model Creative Problem Solving (CPS) untuk meningkatkan kemampuan berpikir kreatif matematis siswa. Prisma, 8(2), 182-190.

Udayani, I. D. A. T., \& Agustika, G. N. S. (2020). Pengaruh model Creative Problem Solving terhadap minat belajar matematika. Jurnal Imiah Pendidikan dan Pembelajaran, 4(2), 284-293.

Yuliati, Y., \& Lestari, I. (2019). Penerapan model Creative Problem Solving untuk meningkatkan hasil belajar siswa pada pembelajaran Ilmu Pengetahuan Alam di Sekolah Dasar. Jurnal Cakrawala Pendas, 5(1), 280138. 